\title{
14
}

\section{8 in German-speaking Switzerland: Controversies and Interpretations}

\author{
Nadine Ritzer
}

'1968' has become an 'associative space of societal attributions and authorial interpretations of the self' (Frei 2008, 211). A study of the Swiss print media of the time reveals that two protests in particular had been responsible for moving public opinion in 1968, both of which relate to the Cold War to an equal extent: protests against the repression of the Prague Spring and against the war in Vietnam (Kleger 1999). Both events are distinctive in that they thoroughly destabilise bipolar constructions of the Cold War.

Reformers in the circles of Alexander Dubček and Ludvík Svoboda were fighting neither for liberalism nor for capitalism; rather, they sought a brand of socialism with a human face (Karner 2008). This is why anticommunist interpretations of the Prague Spring generally fall short. More recent studies now read the events in Prague as part of the international 68 movement and emphasise parallels between the forms of action taken and the demands made by both East and West (Frei 2008, 190-197). Similarly, the war in Vietnam and the role of the USA as an advocate of

N. Ritzer $(\bowtie)$

Pädagogische Hochschule Berne, Berne, Switzerland e-mail: nadine.ritzer@phbern.ch 
freedom and democracy are radically questioned. At the same time, the war in Vietnam had always been more than a mere proxy war in the EastWest conflict. Many historians assume today that the North-South component was just as significant as the East-West aspect: '[...] the First Indochina War was simultaneously a colonial conflict and a Cold War confrontation', writes Fredrik Logevall $(2010,286)$, for instance. Others even maintain that from the 'third world' perspective there were hardly differences between the superpowers that were the USSR and the USA (Westad 2000, 564).

With this in mind, this chapter inquires as to how the Prague Spring and the Vietnam War have been and continue to be interpreted in schools in German-speaking Switzerland, based on three source types: teacher periodicals from the relevant period, ${ }^{1}$ history textbooks from the relevant period and the present day, and teacher interviews. ${ }^{2}$ The study design is informed by two key lines of inquiry: How homogeneous or controversial have the various interpretations negotiated in different media been and to what extent do these controversies continue? Can shifts in these interpretations be identified over the course of time?

The results of the comparative study unveil ambivalences that surprisingly recur in all analysed formats, indicating that both events were from the outset too complex to be mapped within a simplistic structure of East/West dualism.

\section{Switzerland in the Cold War}

While Switzerland assumed an officially neutral position in the Cold War, it was western-oriented in terms of ideology, economy, geography and national policy. This was not least evident in its generally anti-communist stance, shared by the population at large as well as the prominent political parties. As Kurt Imhof (1999) emphasises, anti-communism served as a societal 'basic consensus', a buttress of Helvetian identity construction and 'organising principle of political communication'. The latter also informed the school, which - in the context of the so-called 'spiritual national defence' (Geistige Landesverteidigung) - also sought to 'arm' its young people for the fight against communism (Ritzer 2015, 129-162). Events in Czechoslovakia in 1948 and Korean War had fuelled fear of the 'red men- 
ace'. In 1951, the Swiss Federal Council issued a secret decree on 'preserving national security', which led to some 900,000 persons being registered by the state on lists of potentially suspicious individuals. It was not until these surveillance mechanisms were unveiled in the so-called 'secret files scandal' (Fichenaffäre) of 1990 that the decree was revoked (BretscherSpindler 1997, 213; Kreis 1993). Although Switzerland was shocked and unsettled by the scandal, the resulting reinterpretation of the events of the Cold War was nevertheless slow in coming.

\section{The Early Autumn of the Prague Spring}

The violent end to the Prague Spring brought by the Warsaw Pact troops shaped the news reports in Swiss media like no other event in 1968 (Kleger 1999). Thousands of Swiss citizens, including entire school classes, took to the streets in order to protest against 'the Russians'. During a special session of the national council, Walther Hofer declared the solidarity of 'freedom-conscious Switzerland' with the 'violated' people of Czechoslovakia. Switzerland, he proclaimed, was appalled by the infringement of 'the right of self-determination of a small state and of its endeavours towards a selfdefined and independent existence' (www.dodis.ch/32187, 2). Federal Council President Willy Spühler evoked an instructive lesson to the Swiss people not only to remember the value of, but also to defend, their own civil liberties. Members of parliament praised in particular the commitment and enthusiasm of young people for the flame of freedom being ignited amongst the Czechoslovakian people (www.dodis.ch/32187, 29-33). The SLZ considered it the 'serious duty of all teachers' to address these events in class (N.N., SLZ 113, 1968, 1315).

\section{Contemporary Interpretations in the Teacher Periodicals}

In July 1967, twenty Czechoslovakian teachers paid a visit to members of the Swiss Teachers' Association, who returned the visit in Czechoslovakia in the spring of 1968 . This visit was intended to significantly shape initial interpretations of the Prague Spring and indeed was subject to detailed 
commentary in various reports following the crushing of the Prague Spring (Hänni, SLZ 113, 1968, 1299; Adam, SLZ 113, 1968, 1299-1310 and 1350-1357). These interpretations repeatedly moved beyond the bipolar structure conventionally applied to the Cold War. The reports focus on the political euphoria in the ČSSR and the cautious optimism of the host teachers: 'We felt so free, we could have been anywhere', a member of the Association described the atmosphere in Prague in the spring of 1968 (Adam, SLZ 113, 1968, 1354). The reporter emphasises the openness of the people, who were speaking - uninhibited by the recently lifted censorship of the press - of old grievances and new hopes. In these jubilant days, one teacher writes, public criticism on the part of artists and intellectuals had become a thing of possibility (Adam, SLZ 113, 1968, 1350-1357). What were perceived as the objectives of the 'Czech Revolution'? The ČSSR was in the process, thus the general theme, of 'becoming a democratic socialist state', a state with 'all civil liberties' (Adam, SLZ 113, 1301). The Swiss seemed to believe that the Czechoslovakians found themselves on the threshold of breaking through the conventional dichotomy of 'democracy' and 'socialism', and taking a third path (Adam, SLZ 113, 1968, 1299-1310 and 1350-1357; Hruby, SLZ 114, 1969, 1240-1245). Following the Warsaw Pact invasion, however, the tone of the reports changed somewhat, even in the SLZ. The dichotomous worldview dominated perceptions of the events, which were also interpreted in terms of the national master narrative of a Helvetian 'tradition of liberalisation', as the struggle of an 'enslaved people' for freedom and against Soviet communism. If the report is to be believed, the climate at universities and schools was one of denunciation, intimidation, fear and dismissal, the teachers being held responsible for the 'failure to Sovietise Eastern Europe' (N.N., SLZ 115, 1970, 1572-1575). This led to the Czechoslovakian education system being ransacked in search of 'unreliable persons' by means of 'inquisition papers', demanding all those questioned to inform against critically minded colleagues. Although, according to the SLZ, some 95 per cent of teachers refused to complete the 'inquisition papers', a 'cleansing' of professors and academic staff nevertheless took place (N.N., SLZ 115, 1970, 1572-1575; N.N., SLZ 115, 1970, 115). 
The Swiss teacher periodicals took on the task of denouncing the instrumentalisation of education by these communist governments, and painted pictures of the courageous and clever resistance measures on the part of the people against the system of injustice. Particularly striking is that the teachers were usually portrayed as victims of the regime rather than as the agents and vehicles of the ruling ideology (Ritzer 2015, 85-94). The euphoria in the ČSSR in the spring of 1968 and the quest for a new form of socialism on the part of the 'reform communists' were now hardly mentioned. The protesters were considered role models in the struggle against communism due to their civil courage, working in the interests of 'spiritual national defence' (Frei, PB 62, 1968, 69). The protests in Prague or Bratislava served as a warning to the Swiss to fight to preserve their own civil liberties. Because the martyr image suited the concept of 'intellectual national defence' better than that of reformer, not only the protesters but also the reform communists, in particular Ludvík Svoboda and Alexander Dubček, were celebrated as heroes in the struggle against Soviet communism.

In Switzerland, numerous young people organised demonstrations and rallies. Many teacher teams and education authorities were critical of their political activities. One outraged teacher reported how a colleague had spoken out against young people being encouraged to demonstrate and thus being 'instrumentalised' for other people's ideals; ultimately, young people can be equally motivated to 'do completely the opposite ... as in the case of the Hitler Youth'. Criticising his colleague, the teacher continues: If he, as a teacher, is no longer in a position to clearly condemn 'such a nefarious attack on human rights' and to name the 'culprits', 'if I am no longer in a position to present the judicious courage and resolute determination of the Czech people as an example of civil courage and civic duty, then I can no longer be a teacher. Then I am no more than the infamous "conveyor of facts" (N.N., SLZ 113, 1968, 193-1194). He was not alone. Many teachers were impressed by the initiatives taken by their pupils, supporting or encouraging them to participate in protest marches (N.N., SLZ 113, 1968, 1193-1195; G.S., ScS 55, 1968, 725). ${ }^{3}$ Blue, white and red pennants were displayed on bicycles and cars and flags were carried to demonstration marches and silent protests. During one of the largest demonstrations in Bern, hundreds of pupils - with 
permission from their teachers - performed a sitting strike in front of the Soviet embassy, disregarding, however, police regulations (Schweizer Fernsehen, 21 August 1968).

The SLZ also showed great interest in the youth demonstrations of the CSSR, most of which were portrayed as the spearhead of the anticommunist movement. Only seldom were parallels drawn between the 1968 movements in East and West. The newsletter of the SLV declared the attempt to communise ČSSR youth a failure (N.N., SLZ 115, 1970, 1572-1575). Recent research, however, refutes this claim. The rebellion of Czech youth may have turned against Soviet Orthodox communism; not, however, against reform communism (Karner 2008, 8). Demands were also made for societal change (Frei 2008, 190-197), dramatically exceeding the hopes of many Swiss protesters for the ČSSR. It was only seldom pointed out that the young people of the ČSSR were questioning 'authorities' and criticising the education system as were young people everywhere. Although a speaker pointed to the transnational character of the 1968 protests during a demonstration, at the same time he strongly criticised the 'rebellion' in Switzerland:

Young people in Czechoslovakia also experienced demonstrations and riots only a few months ago. And in Prague too, for the same - quite unspectacular - issues as in almost all large cities of the world. The apprentices, students and pupils who took to the streets in Prague were no more original than their counterparts in Berlin, Rome and Paris. What was unique and exemplary in Czechoslovakia, however, was that it was the young people and not only the much more experienced and mature adults who in the space of these few months had admirably taken on responsibility and selfdiscipline, thus achieving resistance in its most effective form (Fuchs, SLZ 113, 1968, 1195).

Some warned, however, that anti-communist reflexes could not do justice to the complexity of the conflict in the ČSSR. Even some pupils acknowledged that the 'Czechs were and wanted to remain communists, that in this case anti-communism would not have the desired effect' (G.S., ScS 55, 1968, 725). Sociologist Karl Hruby (SLZ 114, 1969, 1244) put it in plain terms at an international teacher conference in 1969: 'No one has demanded that state capitalism - in the East referred to as "socialism" - be 
abolished'. As suggested above, the teachers who reported of the hospitality of their ČSSR friends knew this too, albeit not without emphasising that these 'amiable people are communists who believe in an improved social order and fight for it with honesty and conviction' (Adam, SLZ $113,1968,1299-1310)$. It was the protesters themselves, and not so much the periodicals, who pointed to the ambivalent interpretations that could be applied to the events in the ČSSR: In Basel, the streets echoed with the call of 'Dubček! Svoboda!' Posters drew parallels between the violence in Prague and in Vietnam. Both American and Soviet 'imperialism' were given a harsh verdict: At a demonstration in Basel on $22^{\text {nd }}$ August 1968, protest banners read: 'ČSSR - out with the UdSSR! Vietnam - out with the USA!' (NZZ, 22 August 1968, 4). In Zürich, too, the 'interventions' of both superpowers were denounced by the Progressiven Mittelschüler (progressive Gymnasium pupils) or the Fortschrittliche Studentenschaft (progressive students) (Becker 2014, 60).

\section{The Prague Spring in the Textbooks}

Although the Swiss textbooks for the most part tend to locate the Prague Spring within a bipolar world order, ambivalences are nevertheless perceptible. While a few early portrayals suggest that the Prague Spring sought not to defeat but rather to reform the socialist system, two strands of interpretative thinking were dominant in the 1970s and 1980s. It was only after the end of the Cold War that teaching materials offered a more nuanced depiction of the protagonists and their objectives, albeit retaining the fundamental narrative - in images and text alike - of the struggle of a freedom-loving people against a dictatorial Soviet communism.

A history textbook of 1968 presents interpretive elements that reappear at later intervals: The dispute between the 'Moscow-friendly communists and the innovators', it claims, was won by Alexander Dubček, who relaxed the censorship of the press. 'The elation of young people about this glimmer of liberty compelled Dubček to make further concessions.' This was not tolerated, however, by 'the Russians', who consequently ordered the Warsaw Pact forces to invade (CH-1968-Göldi, 61). According to this interpretation, the 'communists' allowed for the new 
liberties only under pressure; no autonomous will to reform is attributed to them. The dominance of the bipolar logic that informs such interpretations also becomes evident in references to the Brezhnev Doctrine that claim 'Russia' primarily intervened because no satellite state may be allowed to think differently. At the same time, the insurgents were portrayed as martyrs; it had been only their non-violent protest that had prevented further bloodshed. An image of young protesters around and on an army tank, with the caption 'Prague 1968: Not Afraid of Tanks' emphasises the interpretation of the conflict as a struggle between David and Goliath (CH-1968-Göldi, 61).

The history textbook published shortly after the events, Denkwürdige Vergangenheit (1969), briefly indicates the will to reform in the political leadership of the ČSSR. Svoboda and Dubček, the book explains, had attempted to combine the ideals of East and West; to reconcile fraternity and liberty. What exactly this meant was not explained in detail. The responsibility for the repression of the Prague Spring was attributed to the 'Kremlin powers'. Despite its abrupt ending, the textbook claims, the Prague Spring inspired hope, 'for the unanimously non-violent resistance on the part of the Czechoslovakian people bore witness as never seen before to the indestructible power of liberty and spirit. And this witness came from the communist camp' (CH-1969-Müller, 266).

Here too, non-violent protest is a model for the Swiss pupils. This author, however, unlike many articles published in the association newsletters, expressly points out that the insurgents belonged to the 'communist camp' and were not acting in opposition to communism. This interpretation destabilised the bipolar logic of 'spiritual national defence': positive political activity was even possible in the communist camp! This reading tends, however, to constitute the exception to the rule in Swiss textbooks. Portrayals from the 1970s and early 1980s retain the differential semantics of 'freedom and democracy' versus 'coercion and communism'. A widely used textbook, for example, presents a highly emotional depiction of the attempt of 'courageous men' to liberate themselves from the Soviet pressure (CH-1970-Jaggi, 306-307). Here too, the book mentions that the leaders of the protests in the ĆSSR retained communism, albeit with 'as much liberty and humanity as possible'. Was the author suggesting here that most of the insurgents - unlike the leaders - 
were questioning communism? Certainly, the insurgents were depicted as heroes: 'Many women are crying. The men, however, are becoming embroiled in heated debate with foreign soldiers. Their words are lost in the din from the Russian tanks. Foolhardy citizens of Prague succeed in exploding Russian tanks'. Interestingly, the author makes an alteration with regard to those responsible for ending the Prague Spring. In 1970 he had emphasised that 'powerful Russia' had not been willing to grant more liberties (CH-1970-Jaggi, 306). Another version of his history textbook, published eight years later, includes the ruling powers of the Soviet 'subordinate countries' amongst those responsible for the ČSSR invasion, rather than just 'the Russians' (CH-1978-Jaggi, 382).

It was not until the mid-1980s that these narratives shifted. At this time there was also a change in the design of history textbooks. Since the end of the 1970s, increasing numbers of sources had been used, with the intention of inspiring learners to form their own perceptions of history. The book Zeiten Menschen Kulturen (ZMK), published in 1985, for example, primarily features sources. The text describing the Prague Spring was reduced to a table outlining the history of events in the CSSR since 1918, with a focus on structural differences between East and West. The production of consumer goods in the ČSSR had been neglected in favour of heavy industry, leading to a division in the Communist Party between the 'Moscow-faithful' and 'reformers'. Initially, the reformers had prevailed. Their goal had been paving their own way to socialism, 'holding on to communism, but guaranteeing civil liberties', which had been thwarted by the invasion of the 'Warsaw Pact States' (CH-1985-Ziegler, 61-63 and CH-1993-Ziegler, 61-63). Interestingly, ambivalent interpretations were inherent in the sources. Excerpts from the 'Two Thousand Words Manifesto' and the Brezhnev Doctrine were printed, along with an opinion piece by Swiss social democrat Walther Bringolf, who claimed the CPSU had had strategic reasons for hindering the ideological liberation' of the ČSSR from the 'corset of communist discipline'. Were the ČSSR to fall away, he argued, the 'southern flank' of the CPSU would have been open to attack, bringing about the end of the 'Soviet-Russian superpower policy towards the West' (CH-1985-Ziegler, 62 and $\mathrm{CH}-1993-Z i e g l e r, 62)$. The pictorial sources, on the other hand, continue the 'David and Goliath' theme, showing soldiers or tanks in the 
midst of a peaceful demonstration with the caption 'Russian invasion of Czechoslovakia, 1968: Tanks against freedom fighters' (CH-1993-Ziegler, 53). Depite the juxtapositioning of contradictory interpretations of events - the economic East-West divide, the threat to communism posed by the freedom movement in the CSSR and the strategic military motives of the USSR - learners are never explicitly made aware of these differences.

After the end of the Cold War, the portrayal of the Prague Spring gained further in nuance. The history textbook Weltgeschichte im Bild (WiB), volume 9, 1996, was the first to point out that the Communist Party, alarmed by the level of unrest in the country, had placed itself at the 'spearheard of the movement'. Dubček sought to develop a form of communism with 'a human face' (CH-1996-Bühler, 51); indeed, as a pictorial source suggests, 'a deeply democratic society suitable for the Czechoslovakian conditions', having himself initiated the Prague Spring: 'Following a long period of police rule, terror and oppression, now better times seemed to be on the horizon'. But the USSR did not approve of this unique path, the textbook seems to suggest. Accompanied by catcalls, invading tanks of the Warsaw Pact had put an end to the Prague Spring (CH-1996-Bühler, 51). Despite the nuances in the text, the pictorial language continued the established theme.

Differences in living standards between East and West also constituted a theme in a history textbook published after the Cold War with several new issues published over twenty years without any changes to the Prague Spring narrative. The lower standard of living as compared to the West and also the monitoring of the population by the Communist Party had fomented displeasure in a number of countries. As a result, 1968 saw upheaval within the Party in the ČSSR and also various reforms. As the USSR had feared that this development could 'spread to other countries' and endanger the 'communist system of government', it intervened with the purpose of 'saving socialism', establishing a party leadership that reversed the reforms in the ČSSR (CH-2010-Meyer, 73-74). Although this textbook, still used today by some learners, does address the upheaval within the ČSSR Communist Party, the opposition between the protestors and Soviet communism - the pattern 'freedom fighters versus communist oppressors' - remains the central motif of the narrative, echoed in 
the pictorial source (CH-2010-Meyer, 74). Above all, the textbook fails to mention that the reforms were introduced by the communists.

\section{The Prague Spring in Memory Construction}

The teachers interviewed emphasise varying aspects of the Prague Spring: the protests against 'the Russians', the biased anti-communist interpretation of the events, and the general anti-communist feeling in Switzerland.

One teacher, here referred to as Heinz Sutter (*1943), speaks of the demonstration in Bern 'against the Russians', which led to skirmishes with the police, riots and tear gas, as the demonstrators, among them our interviewee, did not follow police instructions. ${ }^{4}$ Protesting against the injustices in Prague and Bratislava therefore did not automatically suggest acceptance of the 'western' order. The protest against 'the Russians' was at the same time a protest against the authorities: against teachers and parents who had forbidden participation, against the government and the police, whose rules were ignored. Not only 'the Russians' were infringing upon the constitutional order; Swiss youth too, blocking the roads, choosing their own demonstration routes and ultimately protesting without permission in front of the Soviet embassy.

As I have shown, some teachers approved of their pupils' demonstrations. One $\left({ }^{*} 1940\right)$ reports that his pupils, like many others, had demanded permission to demonstrate 'for Czechia', which, 'of course', was granted:

They [the pupils, N. R.] extended breaktime, assembled and marched across the playground. They were carrying a Czechian flag and shouting 'Dubček! Svoboda! Dubček! Svoboda!' They knew about demonstrating from the news media and had been so moved by it that they wanted to take an active part themselves. It really made an impression on us. ${ }^{5}$

Another interviewee $\left({ }^{*} 1944\right)$ reminds us that the shouts of 'Dubček and Svoboda' were for most people the call for a new, anti-communist beginning. ${ }^{6}$ He himself, under observation by state security due to numerous trips to Eastern Europe, questioned this reading, emphasising that protesters in the ČSSR sought to re-examine, but not overcome, communism. At 
the same time he pointed out that 'people' certainly sympathised with some ideas of the Eastern bloc. 'One', he continued, had the feeling that 'socialism with a human face' would be an interesting model with future potential. ${ }^{7}$

A secondary-school teacher (Gymnasium, *1958), reports that he had heard about events in the CSSR in the primary school and on the radio and 'simply understood that it was the evil Russians occupying a peaceful country and population against their will, and that that's a bad thing'. Another teacher $\left({ }^{*} 1961\right)$ mentions the many sources of information, unable to recall from whom he had heard what exactly was happening in the ČSSR. In his recollection, television images and newspaper reports are blended with explanations from his parents. His father was an officer and as a boy he had learnt that the USSR constituted a permanent threat, which influenced his understanding of the events in Prague. ${ }^{9}$ Today, his memory of the protests is overshadowed by his memory of a new Czechoslovakian schoolmate, a refugee.

\section{The Vietnam War in Focus}

In Switzerland too, the 68 movement brought protests against the war in Vietnam onto the streets and into the lecture halls. As early as 1965, the organisation Fortschrittliche Studentenschaft Zürich (Progressive Students of Zurich), convened a 'teach-in' at the ETH Zurich on the conflict in Indochina, understood here as a result of colonialism and imperialism (Peter 2008, 62-73). In this sense, the Swiss critics of the Vietnam War were part of the 'counter-cultures' described by Jeremi Suri, who fought against 'imperialism' and 'fascism', thus casting doubt on the 'Cold War order' (Suri 2010, 470). In Switzerland there was a growing debate in the Vietnam War context about the forms which 'development aid' and solidarity with the 'third world' should take (Holenstein 1998, 115-125). At the same time, interdependencies between the 'Third World problem' and the Cold War led to public discourse on the Vietnam War shifted the East-West dualism into one of North and South. The result was that anticommunism decreased in credibility as a sustainable basic consensus for civil society (Imhof 1996, 26-27). 
Further, the Vietnam protests were also the scene of generational conflict. Western Europe's youth questioned the policies of their political leaders and glorified the Viet Cong peasant warriers as well as Mao Zedong or Che Guevara as 'symbols for a revolution against not just political institutions, but the basic organization of society' (Suri 2010, 469). The hippies were only one manifestation of the 'counter-cultures' experimenting with new forms of protest in San Francisco, Prague or Zurich. Various forms of active protest such as American 'anti-Vietnam songs' and peace activists as well as demonstrations, sit-ins and 'teach-ins' are firmly anchored in the Swiss collective memory.

Despite the wide support for the protests, significant voices in Switzerland defended the Vietnam War as a necessary measure to protect against communism and condemned the protests as communist intrigue. In 1966, the Federal Political Department informed the ambassador in Washington, D. C. of an 'extreme left-wing inflitration', a torchlight procession in Bern to protest against the Vietnam War (www.dodis. $\mathrm{ch} / 31167)$. The reporting on the war in Vietnam by the media was also criticised by Peter Sager, founder of the Swiss Ost-Institut, where numerous - often anti-communist - brochures on the Eastern bloc were published for readers including schools. He even considered democracy endangered; it had become impossible, he claimed, to form an objective opinion because the people were overwhelmed by the images and portrayals of Vietnam. He not only rejected the heroising of the Viet Cong as inappropriate; he also compared the war in Vietnam with World War II. Inspired by domino theory, he argued that the Americans in Vietnam must oppose communism, just as the Allied Forces had done with Hitler (Sager 1968, 82).

\section{Contemporary Reception in Teacher Periodicals}

Unlike the daily press (Imhof et al. 1999, 246-249), the teacher periodicals barely registered the war in Vietnam. No discourse relating to the war is discernible in either the SLZ or the ScS, nor did any of the association periodicals comment on the demonstrations. It was not until the USA's retreat that the SLZ addressed the topic, focusing on the humanitarian 
catastrophe and calling for support for the 'International Youth Aid Union' (Internationale Vereinigung für Jugendhilfe) to help children and young war victims in Vietnam (N.N., SLZ 120, 1975, 313). Following the communist annexation of South Vietnam, and the inclusion of the 'Boat People' in the discourse, the SLZ called once again for solidarity with those affected and loudly criticised not only the communist regime but also the 'leftist' students at the University of Bern with their provocative slogan 'No to Hirschy; yes to Giap!'10 (Gut, SLZ 124, 1979). There was no critique of the US warfare, no question of the great western power sharing responsibility for the humanitarian crisis. It was not until 1989, in an article on Vietnam, Laos and Cambodia, that the cause and course of the war was given candid attention (Rudolf, SLZ 134, 1989, no. 9, 14). It is striking that, while the article speaks of 'efforts towards independence', there is no mention of a 'struggle against communism'. Following the author's historical overview of the colonial period, a 'Vietnamese woman' speaks of the era under French rule and the Vietnamese struggle for independence, and then describes - with precise year dates and specialist terms - how the 'cruel rule of terror' under Ngo Dinh Diem 'persecuted all "leftist suspects", supported by the Catholic Church and the USA. She states that the American bombings began in 1965, without, however, mentioning a catalyst for these attacks. She also described the losses on the US side and the end of the war, the forced reunification, and the fact that some 2.5 million people resettled or fled the communist powers (Rudolf, SLZ 134, 1989, No. 9, 14-16). Although at the end of the narrative it was the communist North that showed its ugly face, this presentation breaks through the long-dominant reading of the war in Vietnam as a struggle between communism and capitalism. Criticism of the warring parties was expressed in the depictions of a 'contemporary witness', a popular method often used by history teaching materials.

\section{The Vietnam War in the Textbooks}

As Richard Lachmann and Lacy Mitchell (2014) have shown, the portrayal of the war in Vietnam changed dramatically in American textbooks. While the atrocities of the war were barely mentioned in the 1960 s 
and 1970s, they were given increased attention from the 1980s. This went hand-in-hand with growing criticism of US foreign policy. US textbooks had been placing more value on 'the hellish and personal aspects of the Vietnam War' since the 1990s. Pictorial sources increasingly showed wounded or dead US soldiers, the trauma of the latter depicted in the text, while the Vietnamese victims were still only mentioned in passing. The anti-Vietnam-War protests have only seldom been mentioned until today, although attention paid to this subject is now increasing (Lachmann and Mitchell 2014).

What form does this take in the Swiss textbooks? Although the conflicts in the French colony were already escalating in the 1950s, the conflict in Indochina was ignored by most Swiss textbooks of the 1960s. Even in 1978, the subject was merely a note in the margin of one of the most widely used textbooks of German-speaking Switzerland, stating that communism, propagated by Russia and China, had spread through Indochina as had been the case in Korea. Vietnam was divided, it states, once the USA, NATO and France had deployed 'opposition troops' (CH-1978-Jaggi, 377). The first textbook to mention the war was Denkwürdige Vergangenheit (1969). The author, Otto Müller, dedicates a great deal of attention to the subject of human rights, as well as decolonialisation and the 'third world', unlike the authors of other textbooks (Ritzer 2015, 294-295). Müller mentions the French phase of the conflict in Indochina and the defeat of the colonial power at Dien Bien Phu. The battles ended, Müller continues, with the division of Vietnam into a communist North and 'a dreadful gulf between rich and poor in the South' (CH-1969-Müller, 261), ultimately leading to civil war. In a relatively critical manner for the time, the author notes that the USA supported a government in South Vietnam that primarily backed the interests of large landowners and not those of the desperate rice farmers. Subsequently, however, he is also careful to justify - or at least explain US intervention, with recourse to domino theory: 'They [the Americans; N. R.] wished to prevent the communism that was ruling North Vietnam from coming to power in South Vietnam, possibly even across the whole of South-East Asia' (CH-1969-Müller, 264). No criticism of the US war strategy can be found here; indeed, a critical voice is heard for the first time in a teaching brochure of 1975 , in which the author begins by 
describing the colonial history of Indochina and the French phase of the war in great detail. Here, he mentions both the role of the People's Republic of China in the anti-colonial freedom struggle of the 'Vietnamese Independence League' (Viet Minh) and the ambivalent role played by Ngo Dinh Diem's supporters and the Viet Cong (CH-1975-Göldi, 45-57). Here too, the struggle against communism is given as the reason for the US intervention, triggered by the Tonkin Incident. At the same time, the text repeatedly emphasises that the USA determined the course of the war events. The author harshly scorns the 'war tactics' of the Americans, such as the expulsion of thousands of civilians, the use of new weapons such as cluster bombs and firebombs, and the use of gas and defoliants. The author depicts the My Lai massacre by citing from a source, an unusual method for this author:

The clearer it was becoming to the Americans that the Viet Cong could not be taken, the more they lost control and resorted to massacres. The bestknown example is the obliteration of the My Lay village. Because the Americans believed it to be a Viet Cong stronghold, Leutenant Calley was given the order to eliminate the village and all its inhabitants. Machine guns mowed down men, women and children. No one gave a precise number; it was certainly far more than a hundred. (Excerpt from the booklet Du und der Krieg, quoted in: CH-1975-Göldi, 53)

Within this source, the author not only criticises the murder of women and children on the part of American soldiers; he also provides an explanation for the US atrocities. The guerrilla tactics of the Viet Cong led, he claims, the Americans to 'lose control'. A similar oscillation between naming the horrors of American warfare and putting them into proportion and context can still be perceived in textbooks published towards the end of the Cold War. In the history textbook Weltgeschichte im Bild 9 (WiB) of 1989, for example, we read: 'Because it was impossible to differentiate between the guerrillas and ordinary farmers, the government troops burned suspicious villages to the ground with napalm bombs. In some cases, all inhabitants of a town, men women and children alike, were all killed (CH-1989-Bühler, 60). It is striking that the author speaks of 'some cases'; even the most recent of the textbooks examined insists that the US soldiers were 'at a disadvantage' due to the guerrilla warfare 
tactics and the good camouflage of the Viet Cong. The book sequatiously describes the actions of the US soldiers and their allies as 'retaliatory strikes' for the Viet Cong attacks, pointing out that these strikes often hit innocent civilians (CH-2005-Argast, 124).

It is still striking that criticism of the Americans, not necessarily in line with the general public opinion of the time, is usually 'hidden' within the source texts. This is also the case for the book Weltgeschichte im Bild 9 (WiB) of 1978, which only allocated little space to the Vietnam War. The dichotomised reading of the conflict prevails: 'The Americans took up defence in South Vietnam against the communist North. They did not move from this warzone until after decades of bloodshed' (CH-1978Allemann, 42). This book, otherwise generous with sources, depicts hardly any pictorial or textual sources at this point; the war is not addressed again until in a later chapter, 'Korea - Vietnam', with a pictorial source showing children behind barbed wire, yet without any contextualisation. The text mentioned that the war was extended due to support from the Americans and Chinese. In 1968, it continues, the USA armed 500,000 men against the 'freedom fighter Ho Chi Minh'. The war cost more than two million lives before counting the civilian losses $(\mathrm{CH}-1978$ Allemann, 54). There is insufficient mention of the use of chemical weapons and the atrocities of soldiers; rather, criticism of the USA confined itself to the mild reproach that its intervention prolongued the war. Use of the term 'freedom fighter' for Ho Chi Minh could be interpreted as a quiet expression of sympathy as the term had positive connotations in the context of the Swiss 'tradition of liberation'. It remains open whether the authors considered the war necessary to suppress communism; no verdict is given in the 1985 edition, although critical nuances are perceptible in the source texts. The history textbook Zeiten Menschen Kulturen (ZMK) provides a table showing how the conflict had developed since the 1940s, and names the 'alleged' Tonkin Incident as the catalyst for the first US air raids over North Vietnam. Alongide textual sources of American origin many of which came from the office of President Johnson, who pointed to the necessity of the war against communism - space is also allocated to critical voices, such as that of Ho Chi Minh, denouncing US warfare and 'murder' (CH-1985-Ziegler, 26-31), albeit in the absence of a source to support the charge of 'murder' at My Lais, for instance. 
It was only in history textbooks published towards the end of the Cold War that space was allocated to a discussion of the consequences of the Vietnam War for civil society. In the new 1989 edition of Weltgeschichte im Bild 9 (WiB), the Vietnam War was even made a key topic of the Cold War, and thus contextualised from the outset within the East-West conflict. At the same time, however, the same book also addresses - albeit implicitly - the North-South conflict that manifested itself in the war, via, for instance, depictions from the perspective of a rice farmer struggling neither for communism nor for democracy, but simply for a better life. Similarly, the authors emphasise that it was primarily the high poverty level that had moved the people of South Vietnam to support the 'National Front for the Liberation of South Vietnam' (Viet Cong). Text and images alike sketch a picture of an unequal struggle in which the highly technologized yet powerless USA ultimately surrenders to a badly equipped yet efficient Viet Cong. The consequences of the US intervention, such as destruction by napalm or Agent Orange, were now explicitly mentioned in this textbook, tellingly accusing both sides of torture and murder:

Once it was established that not only the guerrilla fighters but also the American soldiers had tortured prisoners and killed innocent civilians, a storm of protests against the war overcame the USA. Tens of thousands took to the streets. Young men tore up their call-up papers and Vietnam veterans threw their medals of bravery on the steps of the White House (CH-1989-Bühler, 60).

Discussion of the protests against the Vietnam War was also new.

As we have seen, while the 1989 history textbook WiB addresses the North-South component of the Vietnam conflict, it locates the latter primarily within the East-West pattern. This remained the case until 1991, when the textbook Durch Geschichte zur Gegenwart 4 (GZG) expressly discussed the Vietnam War in the chapter 'From Colonisation to the "Third World"', thus removing it from the Cold War context. This shift of emphasis led to a detailed overview of French colonialism becoming integrated into the narrative. The textbook explained that the population's siding with the Vietminh was due to the farmers' hopes for a redis- 
tribution of land (CH-1991-Meyer, 111). The atrocities of the war were portrayed in great detail; the sources provided evidence of napalm, of defoliants and massacres of civilians. Consequently, the book points out in all clarity, the perception of the American role in world politics had shifted dramatically. The former saviour from fascism and communism had now - such was increasingly public opinion - become a butcher. It is also noteworthy how the textbook has recourse to the 'David and Goliath' motif here. The authors suggest between the lines that 'little Switzerland' has far more in common with the small, yet courageous, North Vietnam than with the American giant. This becomes especially clear in an exercise asking the learners whether Switzerland, like North Vietnam, would be able to prevail against a world power (CH-1991-Meyer, 116).

The 2005 textbook, Menschen in Zeit und Raum 9 (MZR) seemed to permenantly oscillate between varying perspectives of the war, which, despite being introduced in the title as a 'proxy war', is traced in its origins back to the Vietminh struggle for independence from imperial France (CH-2005-Argast, 122-125). As soon as the book speaks of dividing the country into a 'communist and a capitalist part' (CH-2005Argast, 122), however, the East-West dualism regains in dominance. Although learners read that Ho Chi Minh was drawn to socialist and communist ideas primarily in his desire to reform the economy and society following the effects of colonialisation, the text continues to state that the Vietminh considered the 'European forms of state' unjust, partly due to their colonialist association. Later again, however, the text claims that China and the USSR had encouraged the communist aspects of the reform. At the same time, the alliance of the USA with the 'dictatorial president' in South Vietnam is given cautious justification on the basis of domino theory and containment: 'For the USA, the government leader Diem - despite the lack of democracy in his own dealings - was a reliable ally in the battle against communism' (CH-2005-Argast, 123). MZR also discusses the devastating consequences of the war for the Vietnamese civilian population and for the American veterans. With this war, the book concludes, the USA has damaged its reputation in the world.

We can thus ascertain that the textbooks, similar to the case of the Prague Spring, reveal continuities in their interpretative patterns; however, the shifts are more dramatic than in the narrative of the protest 
movement in the ČSSR. As early as 1969 there were first signs of a NorthSouth reading of the conflict, as is the case in research today; the bipolar logic being especially dominant in the 1970s. Domino theory, based on an East-West divide, is repeatedly referred to in the context of motives for the American intervention. Towards the end of the Cold War, the dominance of these dichotomous readings was to a certain extent destabilised. References to French colonialism became more explicit and discussion of social injustice became more important. However, the 1991 textbook explicity located the conflict in Indochina within the decolonisation context, thus introducing the ' 68 discourse' to the classroom. Yet the most recent textbook under analysis, published in 2005, still refers to the Vietnam War as a proxy war between communism and capitalism.

The US' form of warfare was criticised as early as 1975, much earlier than in the American textbooks, and often sources are used to express critique. At the same time, and still today, Swiss authors explain the atrocities committed by the USA and its allies with an apologetic description of the soldiers' desperation as a result of the Viet Cong guerilla tactics. Swiss textbooks urge the remembrance of the victims of both sides, although there are only very few images of American victims. The protests in the USA were mentioned only as of 1989, in the margins of textbook narratives, and it is these protests, criticising the 'imperialism' of the West as early as 1968, that constitute the focus of the teacher interviews.

\section{Remembering the War in Vietnam}

These teachers, for whom discussing the events of 1968 means to a large extent discussing the protests agains the war in Vietnam, strays rather far from the interpretative guidelines provided by the textbook. While many emphasise that the war in Vietnam had been a taboo subject during their studies, others recount that they had witnessed the war being taught. This does not mean that all interpretations were 'sayable' everwhere. In debates on whether and how 'contemporary history' should be addressed in history lessons, warning voices advised against 'letting oneself be defined by the events of the day, doing politics rather than history' (Ritzer 2015, 
267-269). Possibly many tutors considered the Vietnam War 'too political' to be discussed in the classroom. At the end of the $1960 \mathrm{~s}$, a too pronounced anti-Americanism did not yet seem opportune, as the following example of a teacher examination reveals. In 1968, a teacher in training referred to in the following as Fritz Meier - was required to discuss the Vietnam War with his pupils in front of the school inspector. In his interview this teacher said that he had heard that the sympathies of this inspector were for America. He 'came to the defence of the Vietnam War' and argued that the USA must protect the world from the communist threat. This must have impressed the inspector; Meier passed the test. ${ }^{11}$ A different teacher, who was having difficulties finding a job on account of his refusal of military service, criticises in an interview that the Americans, and right-wing circles in Switzerland, had attempted to reduce the Vietnam war to an East-West dualism. As a self-avowed 'pacifist student', he believed 'developing countries' to have been exploited in Indochina. ${ }^{12}$ Similarly, a different interview partner $\left({ }^{*} 1950\right)$ reports that he gradually became aware that the Americans were not always the good ones and the communists not always the 'bad'. ${ }^{13}$

\section{Conclusion}

This chapter has sought to fulfil a twofold objective: to render visible the homogeneity of and controversies inherent in interpretations of the Prague Spring and the Vietnam War at different points in time and in different media discourses; and to examine how readings of both events have changed over time. Four key results emerge from the analysis. First, the study has shown that the willingness to address both these topics with a sophisticated awareness of nuance has diminished with time. While in the 1960s, varying readings are perceptible in the sources analysed, from the 1970s onwards the dominant interpretations were those which followed a bipolar logic, thus gaining compatibility with other prevailing Cold War discourses (Ritzer 2015). With increasing distance to the event there seems to have been a cementing of the narrative; indeed, an ideologism of the various readings. 
Second, two factors inspiring change in the textbooks were identified: innovative design of the medium textbook, leading to more multiperspectivity via sources, which were sometimes contradictory in nature; and the end of the Cold War itself, which required a (if only partial) reorientation process on the part of society, to reflect the historico-cultural work that bore witness to these events of 1968. The conflict over the Vietnam War, for example, reflected historical and cultural manifestations. It was in the context of the Vietnam War debate that textbooks from 1990 onwards articulated more scathing criticism towards the Western hegemonic power that would not have been possible before. In the Prague Spring discourse, on the other hand, despite two main nuances from 1990 onwards, elements of continuity with key interpretative patterns of 'spiritual national defence' can still be observed. Third, we have seen that the debate surrounding the war in Vietnam in German-speaking Switzerland was much more controversial than that on the Prague Spring. Fourth, in the light of the present day, we can ascertain that the teachers interviewed certainly deviated from the readings prescribed by the textbooks, by locating the Vietnam War more clearly within the context of the 'Third World problem', for example. They were thus also criticising the long-dominant concepts prevailing in Switzerland of 'spiritual national defence' and the 'semantic gap' with regard to the EastWest conflict.

As a whole, the analysis shows that interpretations of the Prague Spring and the Vietman War based on a bipolar understanding of the Cold War are repeatedly destabilised in all media formats examined in the study, even if the occasional clichéd idea remains even today. Interpretations of the Cold War have thus become more fluid and fragmented, as if the ideologically painted narratives have been gradually deconstructed; certainly a result of the fading concept of 'spiritual national defence' as well as the end of the Cold War itself.

\section{Notes}

1. The periodicals analysed are the Schweizerische Lehrerzeitung (SLZ) (with no religious affiliation) and Schweizer Schule $(\mathrm{ScS})$, published by the Catholic Teachers' Association. 
2. The study is based on interviews with 27 teachers, 17 of which were guided interviews conducted during my doctoral research on the Cold War in Swiss schools (Ritzer 2015). Ten further interviews were conducted by Nora Zimmermann for the international research project, Teaching the Cold War-Memory Practices in the Classroom, whom I thank for access to the data. All interviews are cited by their assigned number, date, and the interviewee's country of origin ( $\mathrm{CH}$ for Switzerland).

3. See also interview with CH12 (24 March 2010).

4. Interview with $\mathrm{CH} 13$ (26 March 2010).

5. Interview with $\mathrm{CH} 12$ (24 March 2010).

6. Interview with CH16 (1 April 2010).

7. Interview with $\mathrm{CH} 18$ (1 April 2010).

8. Interview with $\mathrm{CH} 03$ (27 August 2014).

9. Interview with $\mathrm{CH} 04$ (20 November 2014).

10. In February 1973, Hirschy was to give a guest lecture at the University of Berne on the valeur éducative of the army. The lecture was howled down by the students (Rogger 2008, 29-31). Giáp was a leading military strategist of the Viet Minh.

11. Interview with $\mathrm{CH} 19$ (9 April 2010).

12. Interview with CH11 (22 March 2010).

13. Interview with $\mathrm{CH} 17$ (29 March 2010).

\section{Bibliography}

\section{Sources}

\section{Textbooks}

(MZR) Argast, R., A. Binnenkade, F. Boller and P. Gautschi. 2005. Menschen in Zeit und Raum 9. Viele Wege - eine Welt. Erster Weltkrieg bis Globalisierung. Aarau: Lehrmittelverlag des Kantons Aargau.

Göldi, H. 1968. Die Russische Revolution. Wattwil: Artel.

Göldi, H. 1975. Weltgeschichte 1945 bis 1975. Wattwil: Artel.

Jaggi, A. 1970. Aus Welt- und Schweizergeschichte seit 1815: ein Lesebuch für die bernischen Primarschulen. 3rd edn. Berne: Paul Haupt und Staatlicher Lehrmittelverlag. 
Jaggi, A. 1978. Von den Anfängen der Reformation bis zur Gegenwart. Welt- und Schweizergeschichte: Lehrbuch für untere Mittelschulen. 5th edn. Berne: Paul Haupt und Staatlicher Lehrmittelverlag.

(GZG) Meyer, H. and P. Scheebeli. 1991. Durch Geschichte zur Gegenwart 4. Zurich: Kantonaler Lehrmittelverlag.

(GZG) Meyer, H. and P. Scheebeli. 2010. Durch Geschichte zur Gegenwart 4. 7th edn. Zurich: Kantonaler Lehrmittelverlag.

Müller, O. 1969. Denkwürdige Vergangenheit. Welt-und Schweizergeschichte. Vol.

2. Aarau: Kantonaler Lehrmittelverlag.

(WiB) Nordwestschweizerische Erziehungsdirektoren-Konferenz (1974-1978).

1978. Weltgeschichte im Bild. Lehrmittel der Welt-und Schweizergeschichte für das 6.-9. Schuljahr. 4 Vol. Solothurn: Lehrmittelverlag des Kantons Aargau.

(WiB) Nordwestschweizerische Erziehungsdirektoren-Konferenz (1986-1989).

1989. Weltgeschichte im Bild. Lehrmittel der Welt- und Schweizergeschichte für das 6.-9. Schuljahr. 4 Vol. New edn. Buchs: Lehrmittelverlag des Kantons Aargau.

(WiB) Nordwestschweizerische Erziehungsdirektoren-Konferenz. 1996. Weltgeschichte im Bild. Lehrmittel der Welt- und Schweizergeschichte für das 6.-9. Schuljahr. 4 Vol. 5th edn. Buchs: Lehrmittelverlag des Kantons Aargau. (ZMK) Ziegler. P. 1985. Zeiten, Menschen, Kulturen 9. Zurich: Lehrmittelverlag des Kantons Zürich.

(ZMK) Ziegler, P. 1993. Zeiten, Menschen, Kulturen 9. Zurich: Lehrmittelverlag des Kantons Zürich.

\section{Periodicals}

Adam, H. 1968. 'Prager Tagebuch'. SLZ 113: 1299-1310 and 1350-1357.

Fuchs, P. 1968. 'Liebe Schülerinnen und Schüler, liebe junge Zuhörer'. SLZ 113: 1195.

Frei, W. 1968. 'Schulsynode des Kantons Zürich'. Der Pädagogische Beobachter 62: 69.

Gut, T. 1979. 'Zweimal Vietnam'. SLZ 124: 19.

G.S. 1968. 'Pauschalurteile sind gefährlich'. ScS 55: 725.

N.N. 1968a. 'Der moderne Geschichtsunterricht'. SLZ 113: 1315.

N.N. 1968b. 'Verlautbarung'. SLZ 113: 1063.

N.N. 1968c. 'Die Demonstration'. SLZ 113: 1193-1195.

N.N. 1970a. 'Ein geplagtes Volk'. SLZ 115.

N.N. 1975. 'Für die Kinder in Vietnam'. SLZ 120: 313. 
N.N. 1970b. 'Hexenjagd an den tschechoslowakischen Universitäten und Schulen'. SLZ 115: 1572-1575.

Hänni, R. 1968. 'Schweizer Lehrer in der Tschechoslowakei'. SLZ 113: 1299. Hruby, K. 1969. 'Politische und geistige Entwicklung eines autoritären Systems'. SLZ 114: 1240-1245.

Rudolf, H. 1989. 'Indochina'. SLZ 134, no. 9: 14-16.

\section{Diplomatic Documents}

Nationalrätliche Kommission für auswärtige Angelegenheiten, Ständerätliche Kommission für auswärtige Angelegenheiten. Protokoll der ausserordentlichen, den Vorgängen in der Tschechoslowakei gewidmeten Sitzung vom 23.8.1968 in Bern. https://dodis.ch/32187 (last accessed 31 May 2018).

Eidgnössisches Politisches Departement. H. Kaufmann an die Schweizerische Botschaft in Washington: Vietnam-Demonstration der 'Jungen Sozialisten' in Bern vom 28.11.1966. https://dodis.ch/31167 (last accessed 31 May 2018).

\section{Further References}

Kanyar Becker, H. 2014. Prager Frühling und die Schweiz 1968-2008. Exhibition documentation, Basel.

Bretscher-Spindler, K. 1997. Vom heissen zum kalten Krieg: Vorgeschichte und Geschichte der Schweiz im Kalten Krieg 1943-1968. Zurich: Orell Füssli.

Frei, N. 2008. 1968 Jugendrevolte und globaler Protest. München: Deutscher Taschenbuch Verlag.

Holenstein, R. 1998. "Es geht auch um die Seele unseres Volkes". Entwicklungshilfe und nationaler Konsens'. In Dynamisierung und Umbau. Die Schweiz in den 1960er und 70er Jahren, Die Schweiz: Staat - GesellschaftPolitik 1798-1998, edited by M. König, G. Kreis, F. Meister and G. Romano, 115-125. Zurich: Chronos-Verlag.

Imhof, K. 1999. 'Entstabilisierung. Zukunftsverlust und Komplexitätsreduktion in der öffentlichen politischen Kommunikation der 60er Jahre'. In Vom Kalten Krieg zur Kulturrevolution. Analyse von Medienereignissen in der Schweiz der 50er und 60er Jahre, edited by K. Imhof, H. Kleger and R. Gaetano, 35-54. Zurich: Seismo. 
Imhof, K., H. Kleger and R. Gaetano, eds. 1999. Vom Kalten Krieg zur Kulturrevolution. Analyse von Medienereignissen in der Schweiz der 50er und 60er Jahre. Zurich: Seismo.

Imhof, K. 1996. 'Das kurze Leben der geistigen Landesverteidigung. Von der 'Volksgemeinschaft' vor dem Krieg zum Streit über die 'Nachkriegsschweiz' im Krieg'. In Konkordanz und Kalter Krieg. Analysen von Medienereignissen in der Schweiz der Zwischen- und Nachkriegszeit, edited by K. Imhof, H. Kleger and R. Gaetano, 19-83. Zurich: Seismo.

Karner, S. 2008. 'Der Prager Frühling, Moskaus Entscheid zur Invasion'. Aus Politik und Zeitgeschichte 20: 6-18.

Kleger, H. 1999. 'Normalfall und Sonderfall: Unheimliche Stabilität bei rasanten Veränderungen 1956-1963'. In Vom kalten Krieg zur Kulturrevolution. Analyse von Medienereignissen in der Schweiz der 50er und 60er Jahre, edited by K. Imhof, H. Kleger and R. Gaetano, 191-234. Zurich: Seismo.

Kreis, G., ed. 1993. Staatsschutz in der Schweiz: die Entwicklung 1935-1990. Eine multidisziplinäre Untersuchung im Auftrag des schweizerischen Bundesrates. Berne/Stuttgart/Wien: Haupt.

Lachmann, R. and L. Mitchell. 2014. 'The Changing Face of War in Textbooks: Depictions of World War II and Vietnam, 1970-2009' Sociology of Education 87: 188-203.

Logevall, F. 2010. 'The Indochina Wars and the Cold War 1945-1975'. In The Cambridge History of the Cold War. Volume II. Crises and Détente, edited by M. P. Leffler and O. A. Westad, 281-304. Cambridge Histories Online. Cambridge: Cambridge University Press.

Peter, N. 2008. 'Wilhelm Tell, Marianne und Ho Chi-Minh - Vietnamsolidarität in den 60er Jahren'. In Zürich 68. Kollektive Aufbrüche ins Ungewisse, edited by E. Hebeisen, E. Joris and A. Zimmermann, 62-73. Baden: Hier und Jetzt. Ritzer, N. 2015. Der Kalte Krieg in den Schweizer Schulen. Eine kulturgeschichtliche Analyse. Berne: hep.

Rogger, F. 2008. 'Holz-Affäre und Hirschy-Krawall - die 68er an der Uni Bern'. UniPress 137: 29-31.

Sager, P. 1968. Berichte aus Vietnam. Tatsachen und Meinungen. Bern: Verl. Schweizer. Ost-Institut.

Suri, J. 2010. 'Counter-Cultures: The Rebellions against the Cold War Order, 1965-1975'. In The Cambridge History of the Cold War. Volume II. Crises and Détente, edited by M. P. Leffler and O. A. Westad, 460-482. Cambridge Histories Online. Cambridge: Cambridge University Press.

Westad, A. O. 2000. 'The New International History of the Cold War: Three Possible Paradigms'. Diplomatic History 24, no. 4: 551-565. 
Open Access This chapter is licensed under the terms of the Creative Commons Attribution 4.0 International License (http://creativecommons.org/licenses/ by/4.0/), which permits use, sharing, adaptation, distribution and reproduction in any medium or format, as long as you give appropriate credit to the original author(s) and the source, provide a link to the Creative Commons licence and indicate if changes were made.

The images or other third party material in this chapter are included in the chapter's Creative Commons licence, unless indicated otherwise in a credit line to the material. If material is not included in the chapter's Creative Commons licence and your intended use is not permitted by statutory regulation or exceeds the permitted use, you will need to obtain permission directly from the copyright holder.

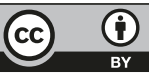

